\title{
Correlation of branches of law in environmental and legal support of the development of the Arctic region
}

\author{
Elena Nikolaevna Abanina ${ }^{1 *}$, Nikolay Ivanovich Makhonko', Yulia Anatolievna \\ Plotnikova $^{1}$, Elena Anatolievna Tarasova ${ }^{1}$, and Irina Vasilievna Shvetsova ${ }^{2}$ \\ ${ }^{1}$ Saratov State Law Academy, Land and Environmental Law Department, Saratov, Russia \\ ${ }^{2}$ Saratov State Law Academy, Department of Financial, Banking and Customs Law, Saratov, Russia
}

\begin{abstract}
The purpose of the study is to analyze individual independent branches of law included in environmental law and their variability in determining special approaches to the development of the Arctic in modern geopolitical conditions. The methodological basis of the research includes the general scientific method and special methods of cognition, such as comparative legal, environmental legal, statistical and empirical. The results of the study are the conclusions from the analysis of the main program and legal documents regulating the development and development of the territories of the Arctic states. Moreover, the attempts to create an adequate system of convergence of national and international legal regulation in order to determine the modern legal regime of the Arctic are discussed herein. The study of international and domestic experience has shown the need for a correlation of individual branches of law (international, administrative, criminal, informational) with the environmental law to provide comprehensive environmental and legal support for the development of the Arctic region. The authors also draw attention to the fact that environmental and legal problems of the development of the Arctic region require a systematic approach. The novelty of the study lies in the conclusion that, despite the fact that each state of the Arctic region has a national strategy for the development of its Arctic territory, on most topical issues these strategies are of a similar nature and have common approaches: scientifically based methods of managing the natural resources of the Arctic region; special methods of socio-economic development; preservation of vulnerable Arctic ecological systems and scientific activities in the field of climate change.
\end{abstract}

Keywords: the Arctic, the Arctic "five" states, environmental law, ecological systems

\section{Introduction}

The development of the Arctic region as a strategic base providing the states with mineral and biological resources is currently acquiring special importance [1]. In the context of this work, the point at issue are the Arctic states, represented by the countries whose territories

* Corresponding author: elena-abanina@yandex.ru 
adjoin the territories of the northern Arctic, i.e. Russia, the Kingdoms of Denmark and Norway, Canada and the USA [2]. The comprehensive development of the Arctic region contributes to the stabilization of the position of these states in the political arena and world economic markets. To improve the efficiency of public administration in the development of the Arctic region, all countries need to identify not only national priorities in this direction, but also those objective natural and climatic features that should be taken into account when solving economic and social problems [3]. Speaking about the matters related to the development of the region, the particular concern of specialists about the low stability of the ecological system of the Arctic [4], the state of which is rapidly deteriorating as a result of dynamic climatic changes and the negative impact of the industrial development of the Arctic territories, should be noted [5].

\section{Methods}

The methodological basis of the research includes the general scientific method and special methods of cognition, such as comparative legal, environmental legal, statistical and empirical. The paper analyzes the level of the main strategic and legal documents regulating the environmental and legal support of the activities of the Arctic "five" states in the field of exploration and development of the Arctic region. The problems of forming an optimal balance between national and international legal regulation in determining the legal regime of the Arctic are considered. The degree of dynamics of the correlation of environmental law with other branches of law has been studied.

\section{Results}

The first stage of the study includes the analysis of the distribution of the Arctic territory between the Russian Federation, Denmark, Norway, Canada and the United States of America. This division was based on the direct proportion of the correspondence between the length of the northern borders of these states and the ratio of the total area of the Arctic region. The results of the distribution of the Arctic territory for the abovementioned countries are presented in Table 1.

Table 1. Distribution of the Arctic area by countries of the Arctic region $\left(\mathrm{km}^{2}\right)$.

\begin{tabular}{|c|c|c|c|c|}
\hline Russia & Denmark & Norway & Canada & USA \\
\hline 4769508 & 2167485 & 174350 & 3921739 & 1723337 \\
\hline
\end{tabular}

The determination of the regional composition of the territory of the Arctic zone is the most important issue for each Arctic state. A schematic representation of regional compositions for the Arctic states is presented in Table 2.

Table 2. The territory of the Arctic: countries and regional composition.

\begin{tabular}{|c|c|}
\hline Country & Regions \\
\hline Russia & $\begin{array}{c}\text { Land areas, with adjoining internal sea waters and territorial sea, continental shelf, } \\
\text { lands and islands located in the Arctic Ocean, up to the North Pole of the Earth (which } \\
\text { are not the territories of other countries and can be discovered during scientific } \\
\text { expeditions). There are 9 constituent entities of the Russian Federation in these } \\
\text { territories. }\end{array}$ \\
\hline Denmark & Greenland, the Faroe Islands \\
\hline Norway & Nordland, Troms, Finnmark, Svalbard, Jan Mayen \\
\hline Canada & Yukon, Northwest Territories, Nunavut \\
\hline USA & Alaska \\
\hline
\end{tabular}


The spatial approach is required to establish state boundaries; planning the Arctic settlement system and the construction of settlements; to stipulate the indicators of the vulnerability of ecological systems in the Arctic; to substantiate the creation of specially protected natural areas of national and international levels.

At the second stage of the study, the processes of formation of the size and structure of the Arctic population are analyzed as the most important component of the development of the modern Arctic. Definitely, the reclamation and development of the Arctic region is possible only with stable indicators of people who are permanently residing and meet certain requirements. Moreover, medical and geographical requirements are sufficiently unified: health, i.e. the arriving population should be capable of rapid acclimatization, active life and an increase in demography; professional competence; civil, social and economic motivation. Table 3 shows the number of people permanently residing in the Arctic zones.

Table 3. The population of the Arctic region by country (thousand people).

\begin{tabular}{|l|l|l|l|l|}
\hline Russia & Denmark & Norway & Canada & USA \\
\hline 2439 & 108 & 489 & 124 & 737 \\
\hline
\end{tabular}

Modern methods make it possible to predict the processes of population concentration, expansion of the economic infrastructure and urbanization of the Arctic territories based on the improvement of the social sphere and social infrastructure [6].

The third stage of the research includes the analysis of the main documents of Denmark, Norway, Canada, the USA and the Russian Federation, which are represented by legal acts of various levels. The degree of environmental and legal support (documents of various forms and status) for the exploration and development of the Arctic region as a zone of peace and cooperation is presented in Table 4.

Table 4. Legal support for the exploration and development of the Arctic in the states of the Arctic "five".

\begin{tabular}{|c|c|c|c|}
\hline Countries & $\begin{array}{c}\text { National } \\
\text { strategies }\end{array}$ & $\begin{array}{c}\text { Legislative support for the } \\
\text { development of the Arctic at the } \\
\text { national level }\end{array}$ & $\begin{array}{c}\text { Participation in } \\
\text { international treaties and } \\
\text { conventions }\end{array}$ \\
\hline Russia & + & + & + \\
\hline Denmark & + & + & + \\
\hline Norway & + & + & + \\
\hline Canada & + & + & + \\
\hline USA & + & + & + \\
\hline
\end{tabular}

According to the results of comparative analysis, each of the represented countries has sufficiently fully elaborated national strategies for the development of its Arctic territory [7, 8]. It should be noted that the strategies of four foreign states and the Russian Federation for most of the crucial issues not only coincide, but are also quite harmonized in understanding the need to protect the environment, preserve vulnerable Arctic ecological systems and biodiversity.

\section{Discussion}

The study of the degree of development of the Arctic territory by individual European and North American countries, as well as by the Russian Federation, determines the possibility of discussing the issues related to the correlation of branches of law with environmental support for the reclamation of the Arctic region in order to preserve the quality of the environment. The team of authors studied the opinions of respected scientists with interest 
and is ready to discuss the proposed discussion issues. It can be assumed that the issues of the effectiveness of the interaction of environmental law with individual branches of law in the implementation of national strategies for the development of their Arctic territories on the example of the Arctic "five" states will become controversial. Environmental law is aimed at maintaining the necessary balance between the economic and geopolitical needs of modern society and the task of preserving the ecological systems of the Arctic region. The ecological branch of law is of pronounced complex nature, since public relations on the rational use of natural resources and environmental protection are regulated not only by its own norms, but also by the norms of other branches of law. In the context of this study, attention should be paid to the norms of administrative law that ensure the formation of a special order of management in the Arctic zone. It should be noted that the legislation of the countries of the Arctic "five" demonstrate the widespread use of administrative methods in the development of the Arctic territories: programs of state support for economic entities operating in the extreme conditions of the Arctic; state and sponsorship support for scientific research, experimental and experimental work on the implementation of the best environmental technologies and techniques; adaptation of administrative regulations in matters of indigenous minorities. A special role in the protection of the Arctic zone should be assigned to the norms of criminal law. In this regard, the most important problem is the relationship between "action" and "consequences" in relation to environmental crimes committed in the Arctic. The authors note that legal norms containing the grounds for bringing legal entities to criminal responsibility have already been included in the criminal codes of individual states. Information law is also a necessary branch of law for environmental and legal support of all types of activities in the Arctic. There is no doubt that the future of reclamation and development of the Arctic zone is associated with information and communication technologies. Therefore, the operational analysis of the indications of environmental monitoring, provided by information and communication methods, will make it possible to monitor the state of the environment in the Arctic region. International law has a special role to play in correlation with environmental law in order to regulate public relations in the development of the Arctic territories. According to the experts, the system of international interaction and legal regulation of the reclamation of the Arctic has not yet received proper development. Therefore, the states of the Arctic "five" use the format of regional and bilateral cooperation in reclamation and development of the Arctic territory, taking into account their national interests [9].

\section{Conclusion}

The results of the study made it possible to draw certain conclusions and proposals. Environmental and legal problems of reclamation and development of the Arctic region require a systematic approach [10-12]. International law plays a special role in correlation with environmental law to regulate social relations in the development of the Arctic territories. The analysis of international documents made it possible to reveal the following mechanisms of implementation and harmonization: international cooperation [13], modern methods of using Arctic resources, the establishment of special economic regimes, environmental protection and a number of others [14]. The norms of administrative law ensure the formation of a special administrative regime of management in the Arctic zone, which takes into account the uniqueness of the natural system of the Arctic [15]. The crucial role in the protection of the environment of the Arctic zone belongs to the norms of criminal law. The central direction in this area is to reduce the negative impact on the ecological systems of the Arctic zone by establishing an adequate tightening of the responsibility of nature users. However, the issue of recognizing the criminal liability of legal entities for environmental crimes is still controversial in individual countries, including the Russian 
Federation. The efficiency of economic activity in the Arctic and on the Arctic continental shelf should be determined by the effectiveness of the introduction of the latest environmental technologies and methods [16] In this case, information law is a necessary branch of law for environmental and legal support of all types of activities in the Arctic. There is no doubt that the future of reclamation and development of the Arctic zone is related to information and communication technologies [17]. In the future, the norms of environmental law will cover the achievements of the exact, technical and natural sciences. The study of international and domestic experience shows the timeliness of correlation of individual law branches with environmental law to provide comprehensive environmental and legal support for the reclamation of the Arctic region.

\section{References}

1. A. Cherepovitsyn, A. Tsvetkova, N. Komendantova, J. Mar. Sci. Eng. 8(12), 995, (2020). https://doi.org/10.3390/jmse8120995

2. M. Łuszczuk, B. Padrtova, W. Szczerbowicz, Oceanologia, 62(4), 608-621 (2020). https://doi.org/10.1016/j.oceano.2020.03.008

3. V. Leksin, B. Porfiryev, Economy of Region, 13(4), 985-1004, (2017). https://doi.org/10.17059/2017-4-2

4. I. Poiseev, S. Poiseeva, IOP Conf. Ser.: Earth Environ. Sci. 548, 072064

5. A. Novoselov, I. Potravny, I. Novoselova, V. Gassiy, Polar Science, 14, 68-77 (2017). https://doi.org/10.1016/j.polar.2017.10.003

6. N. Tabata, M. Otsuka, M. Goto, Takahashi, Polar Science, 100600 (2020). https://doi.org/10.1016/j.polar.2020.100600

7. P. Berkman, A. Vylegzhanin, O. Young, Baseline of Russian Arctic Laws (Springer Nature Switzerland AG, Cham, 2019). https://doi.org/10.1007/978-3-030-06262-0

8. N. Gagiev, L. Concharenko, S. Sybachin, A. Shestakova, Arctic and North, 41(41), 113-129 (2020). https://doi 10.37482/issn2221-2698.2020.41.113

9. B. Sovacool, L. Noel, J. Kester, G. Zarazua de Rubens, Energy, 165, 532-542, (2018). https://doi.org/10.1016/j.energy.2018.09.110

10. A. Scott, Ecosystems Encyclopedia of the World's Biomes, 409-420 (Elsevier, Amsterdam, 2020). https://doi.org/10.1016/B978-0-12-409548-9.12032-9

11. T.I. Van Pelt, H.P. Huntington, O.V. Romanenko, F.J. Mueter, Marine Policy, 85, 7986 (2017). https://doi.org/10.1016/j.marpol.2017.08.008

12. J. Gibson, Science of The Total Environment, 708, 134538 (2020). https://doi.org/10.1016/j.scitotenv.2019.134538

13. B. Kaiser, M. Kourantidou, D. Ahsan, S. Bakanev, A. Burmeister, G. Eckert, L. Fernandez, H. Hong, A. Monsalve, D. Mullowney, B. Nostvold, H. Park, E. Poulsen, L. Ravn-Jonsen, C. Siddon, J. Sundet, K. Tokunaga, M. Yamamoto, Marine Policy, e127, 104442 (2021). https://doi.org/10.1016/j.marpol.2021.104442

14. C. Prip, Marine Policy, 103768 (2019). https://doi.org/10.1016/j.marpol.2019.103768

15. Aanesen, J. Falk-Andersson, G. Vondolia, T. Borch, S. Navrud, Ocean \& Coastal Management, 153, 157-167 (2018). https://doi.org/10.1016/j.ocecoaman.2017.12.017

16. S. Antipov, N. Didenko, V. Lobatyuk, M. Sosnina, IOP Conf. Ser.: Earth Environ. Sci. 539, 012102. https://doi.org/10.1088/1755-1315/539/1/012102

17. U. Bohlmann, V. Koller, ActaAstronautica, 176, 33-39 (2020).

https://doi.org/10.1016/j.actaastro.2020.05.030 